\title{
The British Association and the Indian Science Congress
}

$\mathrm{T}$ HE majority of the members of the British scientific delegation to the jubilee meeting of the Indian Science Congress Association (see Nature, Oct. 9, p. 609) left Tilbury on November 26, on the $\mathrm{P}$. and $\mathrm{O}$. liner Cathay for Bombay. Some of the party will join the ship at Marseilles, leaving London overland on Thursday, December 2. The British delegation will include representatives of every major department of science; and several distinguished foreign and other representatives have been invited directly by the Indian Science Congress Association; the party will number in all more than a hundred.

The great majority will make a tour through northern India before the Congress in Calcutta, after an official reception in Bombay (December 16-18), and a visit to Hyderabad, where they will be the guests of the Nizam's Government (December 19-21). Agra will be reached on December 22, and Christmas Eve and Christmas Day will be spent in Delhi. At Dehra Dun (December 26) the Forest Research Institute and the Geodetic Branch of the Survey of India will be visited, and there may be an occasion for a run to Mussoorie for the view of the Siwalik Hills and the outer Himalayas. Benares will be visited on December 27-28, and between this and Calcutta a geological party will diverge southward from the railway. Calcutta will be reached on December 29, and as the Congress will not begin until January 3 , it is expected that a number of members will occupy intervening days with excursions to Darjeeling or elsewhere.

It is understood that H.E. the Viceroy will open the Congress, and that Sir James Jeans, as president, will give a brief address and will then communicate to the meeting the presidential address prepared by the late Lord Rutherford, who was to have occupied the president's chair.

The sectional presidents of the Congress are :

(1) Mathematics and Physics, Dr. C. W. B. Normand, director-general of observatories, Meteorological Office, Poona 5.

(2) Chemistry, Prof. S. S. Bhatnagar, director, University Chemical Laboratories, Lahore.

(3) Geology, Mr. D. N. Wadia, officiating superintending geologist, Geological Survey of India, 27 Chowringhee, Calcutta.

(4) Geography and Geodesy, Dr. A. M. Heron, director, Geological Survey of India.

(5) Botany, Prof. B. Sahni, professor of botany, University of Lucknow.

(6) Zoology, Prof. G. Matthai, professor of zoology, Government College, Lahore.

(7) Entomology, Mr. M. Afzal Husain, principal

of the Punjab Agricultural College, Lyallpur, Punjab.

(8) Anthropology, Dr. B. S. Guha, Zoological Survey of India, Indian Museum, Calcutta.

(9) Agriculture, Rao Bahadur T. S. Venkatraman, Imperial sugar-cane expert, Lawley Road, Coimbatore.

(10) Medical Research, Sir Upendranath Brahmachari, professor of tropical medicine, Carmichael Medical College, Calcutta.

(11) Veterinary Research, Sir Arthur Olver, animal husbandry expert, Imperial Council of Agricultural Research, New Delhi.

(12) Physiology, Brevet-Colonel R. N. Chopra, officiating director and professor of pharmacology, School of Tropical Medicine, Calcutta.

(13) Psychology, Dr. G. Bose, University College of Science, Calcutta.

The Congress will run from January 3 until January 9, with an intervening day (January 6) for short excursions. Afterwards some fifty of the B.A. party will visit Madras, Bangalore and Mysore, while others will pay individual visits to other places in connexion with their special scientific interests. A large proportion will leave Bombay homeward bound by the S.S. Strathaird on January 15. Among the party are :

Dr. F. W. Aston.

Prof. F. G. Baily.

Prof. E. C. C. Baly.

Prof. E. Barker.

Prof. V. H. Blackman.

Prof. P. G. H. Boswell.

Prof. A. H. R. Buller.

Prof. P. A. Buxton.

Mr. J. M. Calie.

Prof. G. D. Hale Carpenter.

Prof. N. M. Comber.

Prof. F. A. E. Crew.

Dr. E. M. Crowther.

Prof. Winifred Cullis.

Dr. C. D. Darlington.

Prof. C. G. Darwin.

Mr. T. S. Dymond.

Sir Arthur Eddington.

Prof. C. B. Fawcett.

Prof. W. G. Fearnsides.

Sir Lewis Fermor.

Prof. R. A. Fisher.

Prof. H. J. Fleure.

Prof. F. E. Fritsch.

Prof. R. Ruggles Gates.

Prof. W. T. Gordon.

Prof. J. W. Heslop Harrison.

Sir James Henderson.

Prof. J. Hendrick.

The following non-British men of science will also be among the visitors :

Prof. L. Diels, Botanical Gardens, Berlin.

Prof. F. von Eickstedt, Anthropological Institute,

Breslau.

Prof. C. G. Jung, University of Zurich.

Prof. W. Straub, University of Munich.

Prof. Dr. L. Cipriani, Royal University, Florence. 